\title{
From the ground up: Assessing consumer preferences for multifunctional agriculture
}

\author{
Leah Greden Mathews, University of North Carolina Asheville
}

\begin{abstract}
Submitted 11 May 2011 / Revised 5 September 2011 and 3 October 2011 / Accepted 11 November 2011 /
Published online 21 March 2012

Citation: Mathews, L. G. (2012). From the ground up: Assessing consumer preferences for multifunctional agriculture. Journal of Agriculture, Food Systems, and Community Development, 2(2), 51-69. http://dx.doi.org/10.5304/jafscd.2012.022.011

Copyright (C) 2012 by New Leaf Associates, Inc.
\end{abstract}

\begin{abstract}
Farmland provides more than just food and fiber; it also provides environmental benefits, scenic amenities, a link to our shared cultural heritage, and other benefits. While there is a vibrant literature on the multifunctionality of European agricultural landscapes, few studies examine the multifunctionality of those in the United States. This research provides a detailed, ground-up assessment of the multiple benefits that farmland provides to four counties in western North Carolina. Results outline the numerous benefits provided by rural landscapes and point to the value of a portfolio approach for documenting, monitoring, and financing the benefits of agriculture. The study introduces a replicable method that can be used by communities across the nation to investigate the

Leah Greden Mathews, Department of Economics, University of North Carolina Asheville, CPO 2110, One University Heights, Asheville, NC 28804 USA; +1-828-251-6551; fax +1828-251-6572; 1mathews@unca.edu

Note: The project was supported by the National Research Initiative of the USDA Cooperative State Research, Education and Extension Service, grant 2005-35618-1567.
\end{abstract}

multiple functions of their agricultural landscapes. Widespread and regular use of the method will lead to an improved understanding of the multifunctionality of U.S. agriculture and provide opportunities for effective monitoring and assessment of policies designed to protect these benefits.

\section{Keywords}

community assessment, farmland benefits, geographic information systems (GIS), multifunctionality of agriculture (MFA)

\section{Introduction}

Farmland provides food, fiber, scenic amenities, environmental and ecological services, and other benefits such as cultural heritage and recreation (Bergstrom, Dillman, \& Stoll, 1985; Buckley, van Rensburg, \& Hynes, 2009; Daugstad, Rønningen, \& Skar, 2006; Drake, 1992; Gardner, 1977; Hall, McVittie, \& Moran, 2004; Hellerstein, 2002; Kline \& Wichelns, 1996; McClead, Woirhye, Kruse, \& Menkhaus, 1998; Randall, 2002). Because agricultural lands provide many functions, it is often said that there is a multifunctionality of agriculture (MFA). Markets can provide signals to guide the 
production of some of agriculture's functions (food, fiber), but many of the farm's jointly produced amenities (scenic amenities, cultural heritage, environmental services) are nonmarket goods for which consumers (neighbors, other residents of the community, and visitors) cannot directly express their preferences through normal market channels. As a result, the total value of farmland to communities fails to be accounted for in everyday market transactions.

There is a substantial literature that reports on the willingness of individuals to pay to protect farmland (summarized by Bergstrom and Ready, 2009), which indicates the significant value that farmland provides to individuals and communities. While high levels of public preference for farmland protection are important indicators of general interest in agricultural lands (and perhaps agriculture in general), knowing what people value about agricultural lands is even more helpful for planners and policy-makers. Knowing whether people value land for its productive aspects (food, fiber) and/or nonproductive characteristics (visual amenities, cultural heritage) is key to understanding community preferences for MFA. This knowledge can help local decision-makers, policy-makers, and land trusts in at least three ways: to improve understanding of local resources that can assist with rural economic development and sustainability initiatives (Garrod, Wornell, \& Youell, 2006); to design effective funding mechanisms for farmland protection efforts by targeting stakeholders who receive farmland benefits; and to know where monies will be most effectively invested to correct for market failure and maximize community benefits.

However, we often lack community-based information about the types of benefits that agriculture provides to local areas. Building on surveys of local residents and visitors, in this study we provide a detailed, ground-up assessment of what people perceive as the multiple benefits that farmland provides in four counties in western North Carolina. Results reinforce the demand for multifunctional rural landscapes and point to the value of a portfolio approach for documenting, monitoring, and financing the benefits of agriculture. We developed a replicable method that can be used by communities across the nation to investigate people's understanding and appreciation of the multiple functions of their agricultural landscapes. Widspread and regular use of the method could lead to an improved understanding of the multifunctionality of U.S. agriculture and also provide opportunities for effective monitoring and assessment of policies designed to protect these benefits.

The remainder of the paper is organized as follows: after an introduction to the MFA and review of the MFA literature, the study region is described. The subsequent sections provide an overview of the Farmland Values Project (FVP) and its results. The final sections discuss the results and present implications for other regions and future researchers.

\section{The Multifunctionality of Agriculture (MFA)}

It is widely recognized that agriculture provides benefits other than food and fiber (Bromley \& Hodge, 1990; Duke \& Aull-Hyde, 2002; Kuminoff, 2009; Lynch \& Duke, 2007; Lynch \& Musser 2001; McConnell, 1989; Nickerson \& Hellerstein, 2003). These benefits vary by space and place and can include ecological services such as habitat provision, nutrient cycling, water regulation (flood control), and pollination; landscape services such as scenic quality; food security; recreation; and cultural heritage. Because it provides multiple functions, agriculture has thus come to be referred to as multifunctional. This multifunctionality plays a role in policy settings. The Organization for Economic Cooperation and Development (OECD) agriculture ministers have adopted the concept of multifunctionality as a policy principle, and so MFA is recognized and promoted by policy in the European Union (European Commission, 2004, p. 6; OECD, 2001). MFA has been a controversial element in international trade negotiations when countries act to protect these nonfood or -fiber amenities (Sakuyama, 2005; Swinbank, 2001). Generally speaking, the U.S. has resisted the protection of MFA in trade negotiations, although the U.S. Department of Agriculture clearly acknowledges MFA in its strategic plan that aims to preserve multiple functions of U.S. agriculture (USDA, 2008). 
Hediger and Knickel (2009) provide a thorough summary of the relevance of agriculture's multifunctional benefits for economic welfare and sustainability considerations. Supply-side studies document agriculture's provision of environmental, cultural, scenic, and other services that are jointly produced with food and fiber. Most of these studies have been conducted in Western Europe (e.g., Boisvert, 2001; Lankoski \& Ollikainen, 2001). While it is useful to know how these amenities are supplied by agriculture, it is especially beneficial to know the level of demand (i.e., consumer preferences) for the amenities for effective policymaking.

A majority of the research examining community preferences for MFA has been conducted in Europe. Hall, McVittie, and Moran (2004) provide an excellent review of early studies. They found that most preference studies explored public preferences for a particular rural amenity or set of key features rather than conducting a holistic evaluation of the full set of agricultural functions. Several more recent European studies have attempted to remedy this concern (Hyytiä \& Kola, 2006; Lindemann-Matthies, Briegel, Schupbach, \& Junge, 2010; Parra-López, Groot, Carmona-Torres, \& Rossing, 2008; Sayadi, González-Roa, \& Calatrava-Requena, 2009; Vera-Toscano, GómezLimón, Moyano Estrada, \& Garrido Fernández, 2007).

Interestingly, little research exists that specifically focuses on the demand for MFA in the United States. Moon and Griffith (2010) use a national study to estimate a holistic valuation of the intangible amenities associated with U.S. agriculture. They asked respondents how much the intangible aspects of agriculture were worth to them and the amount of tax they would be willing to pay to retain them. They found that respondents were willing to pay an average of USD515 in annual taxes for the intangible functions of agriculture, which aggregates to USD105 billion annually, and conclude that valuation studies are needed that attach more specificity to the multifunctional attributes of agriculture. In a related study also conducted at the national level, Moon and Chang
(2010) identified factors influencing public attitudes towards MFA. They found that appreciation of food self-sufficiency and ecosystem services are the most significant factors influencing public attitudes toward MFA.

Lenihan, Brasier, and Stedman (2009) sought to measure the perceptions of MFA among rural Pennsylvania residents. They conducted six focus groups in three counties selected for their differences in development pressure and agricultural type and found that the preferences for agriculture's positive characteristics varied among rural areas and social groups. They conclude that policies to promote MFA should be sensitive to local preferences and should provide opportunities for local input, thus underlining the importance of avoiding assumptions of national uniformity of preferences for MFA.

The literature on the demand for the MFA in the U.S. is limited. Our study addresses this gap by adding empirical evidence about community demand for MFA in western North Carolina, a region previously unstudied on this topic and whose agriculture is noted for providing multiple benefits to surrounding areas (Blue Ridge Forever, 2009). Hall, McVittie, and Moran (2004) recognize that some amenities, services, or products that we associate with rural areas require an active local agriculture (landscape, cultural heritage, local food) while others do not (rural character, biodiversity, soil conservation). Irwin, Nickerson, and Libby (2003) observe that policy-makers benefit from learning the relative importance of rural versus farmland amenities in order to improve the targeting of land protection schemes. The challenge for researchers interested in MFA is to be able to identify preferences for agricultural lands that are distinct from preferences for rural lands in general. In our study, we specifically asked participants to focus on the benefits of farmland as opposed to rural lands in general. In so doing, we introduce a novel, ground-up approach to the study of MFA that engages stakeholders in multiple ways to frame the multifunctionality of agricultural lands. 


\section{Setting}

The Farmland Value Project (FVP) was conducted in four western North Carolina counties:

Buncombe, Haywood, Henderson and Madison (see figure 1). These counties were selected because they fall in both the Asheville metropolitan statistical area and the Blue Ridge National Heritage Area, and their agriculture is known for providing multiple benefits to surrounding areas.

The study region contains a diverse but small-scale agriculture; average farm size is 75 acres (30 hectares) (USDA NASS, 2008). The region's agricultural lands are made up of approximately equal shares of cropland, woodland, and pasture (USDA NASS, 2008); due to the mountainous topography, many operations are composed of a combination of woodland with pasture and/or cropland. Historically, tobacco was a predominant crop, as evidenced by the large tobacco barns scattered throughout the region that provide tangible reminders of the area's agricultural heritage. The tobacco buy-out program led most tobacco farmers to seek alternate crops. Vegetable, dairy, and cow/calf operations currently predominate, although there are notable greenhouse operations in Haywood and Henderson counties and significant apple acreage in Henderson County (USDA NASS, 2008).

The four counties together demonstrate a range of urbanization levels. Buncombe County is the most urbanized of the four study counties, followed by Henderson, Haywood, and Madison (see table 1).

Figure 1. Farmland Values Project: The Four-County Study Region

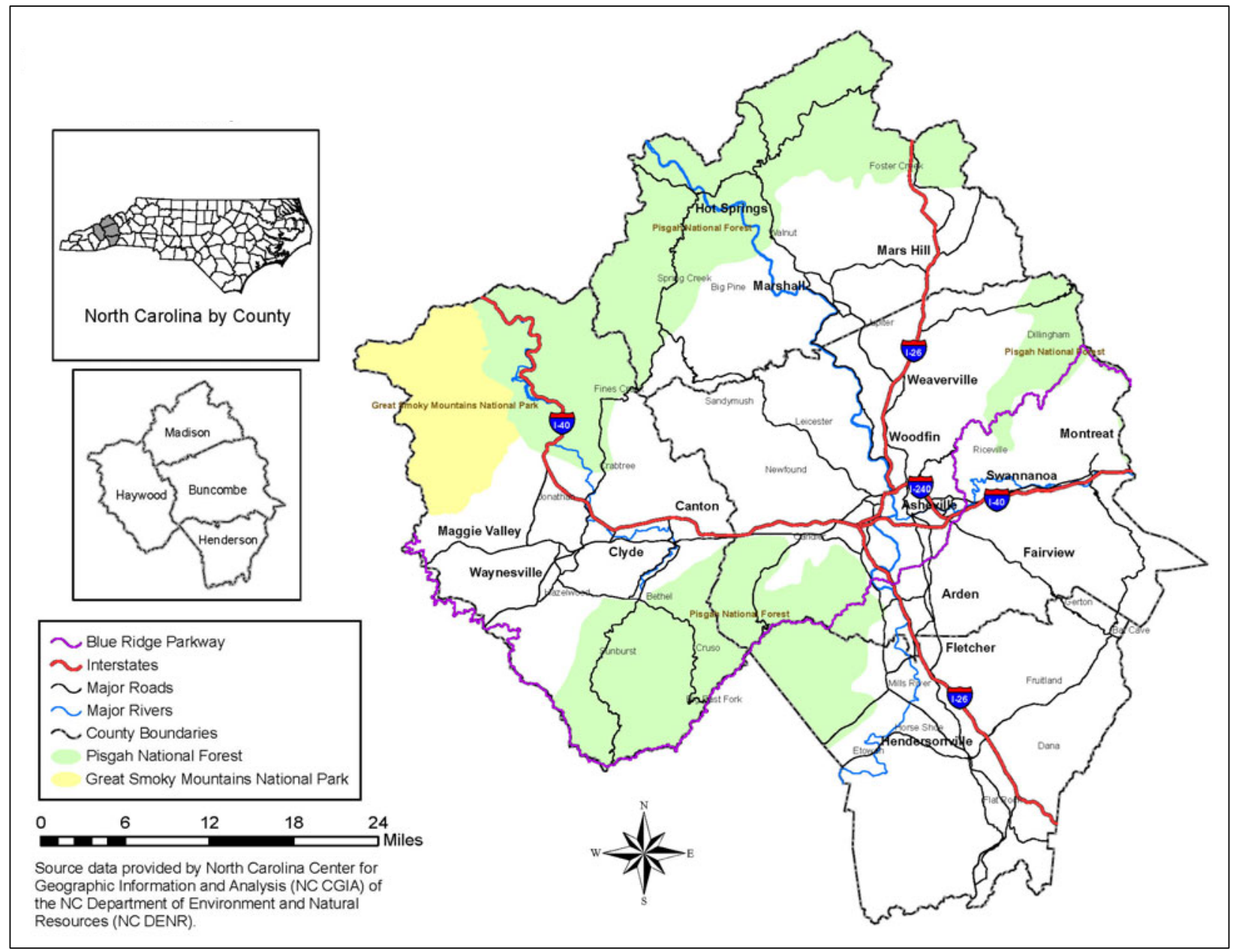


Journal of Agriculture, Food Systems, and Community Development

ISSN: 2152-0801 online

www.AgDevJournal.com

Table 1. Population and Farmland Statistics for Farmland Values Project Study Region

\begin{tabular}{|c|c|c|c|c|}
\hline & Buncombe & Haywood & Henderson & Madison \\
\hline 2010 populationa & 238,318 & 59,036 & 106,740 & 20,764 \\
\hline 2000 land areab (square miles) & 655.99 & 553.66 & 374.00 & 449.42 \\
\hline $\begin{array}{l}2000 \text { population density,b } \\
\text { (persons per square mile) }\end{array}$ & 314.5 & 97.5 & 238.4 & 43.7 \\
\hline Population growth, 2000-2010 & $15.5 \%$ & $9.3 \%$ & $19.7 \%$ & $5.7 \%$ \\
\hline Land in farms 2007 (acres) & 72,087 & 56,212 & 37,947 & 66,734 \\
\hline Farmland loss, c 1997-2007 & $22.97 \%$ & $19.65 \%$ & $27.41 \%$ & $28.49 \%$ \\
\hline
\end{tabular}

Source: a United States Census (U.S. Census Bureau, 2011), b U.S. Census Bureau County Quick Facts (U.S. Census Bureau, 2010), c USDA National Agricultural Statistics Service (USDA NASS, 2008).

Western North Carolina, especially the Asheville area, is popular with tourists and residents seeking natural and cultural amenities. Tourism is a significant economic driver in the region (Evans, Davé, Stoddard, \& Ha, 2006; Starnes, 2005), and the scenic beauty of the region is frequently cited as an important factor in visitation and residential location decisions (Kask, Mathews, Stewart, \& Rotegard, 2002; Mathews, Stewart, \& Kask, 2003). As in other parts of the country, farmland loss has been significant in the study region. In this mountainous area, farmland is often the easiest land to convert to residential or other uses; as a result, farmland conversion rates generally trend with population growth rates. However, the region's relatively more rural counties (Haywood and Madison) still experience significant farmland loss despite slower population growth rates.

Despite the loss of farmland, there is an intense interest in local food in western North Carolina. The Appalachian Sustainable Agriculture Project (ASAP), a local nonprofit based in Asheville (Buncombe County), has championed an extremely effective local food campaign for the last 10 years. Research indicates that demand for local food greatly exceeds the supply; only about $2 \%$ of food consumed locally is produced in the region (Kirby, Jackson, \& Perrett, 2007). In addition to raising awareness about the benefits of local food production for the economy and landscape of the region, and promoting farmers' markets, ASAP has also spearheaded efforts to incorporate local food into schools via its Farm to School and Chefs in
Schools program. There are 22 tailgate markets in the study region, 38 CSAs (community supported agriculture operations) that are regularly fully subscribed, and local wholesale markets that facilitate the incorporation of local food into schools, hospitals, restaurants, and grocery stores (ASAP, 2010). Many people consider Asheville and the surrounding region a "local food hot spot." The Asheville Convention and Visitors Bureau even markets the city to the "foodie" crowd by referring to Asheville as Foodtopia, highlighting the active local food scene along with the city's many independent restaurants and microbreweries that feature local farm products (Buncombe County Tourism Development Authority, 2009).

\section{Study Overview}

Given the interest in local food, concern about farmland loss, and a desire to more fully understand the link between the area's natural resources and community preferences, the FVP was designed to inventory, analyze, and communicate the many different values that people have for farmland in the area. The purpose of the study, conducted 2005-2009, was to better understand the role that agricultural lands play in the hearts and minds of residents and visitors to the region by investigating the many benefits that agriculture provides and their valuation of them.

We utilized multiple methods to learn about the value that residents and visitors placed on farmland in the region. We used focus groups and interviews to gauge interest and identify themes that we then 
used in designing a survey of resident and visitor preferences for farmland. We also developed a participatory geographic information system (PGIS) exercise that enabled residents to specify a particular place in the region that held value for them. The PGIS participants came to a computer lab and, after a brief introduction, used the Google Earth $^{\mathrm{TM}}$ mapping service to pinpoint specific locations that they felt had significant scenic quality or cultural heritage characteristics. Participants were then asked to use their personal values to rate numerically and describe qualitatively the places they identified. In the end, the qualitative and quantitative data from the PGIS and survey were combined and used to enhance a land evaluation site assessment (LESA) model, a numeric rating system created by the USDA Natural Resources Conservation Service (NRCS) to evaluate a parcel's relative agricultural importance (Pease \& Coughlin, 1996). The results of the LESA model demonstrate specific places in the region that hold significant value for residents that can be used to identify priority tracts for protection. Because the PGIS and enhanced LESA model have been described elsewhere (Mathews and Rex, 2011; Rex, Mathews and Lancaster, in press), the remainder of this paper will focus on the results and implications from the FVP focus groups and surveys.

\section{Survey Design and Implementation}

To begin learning about the values for farmland that people in our study region hold, we conducted 17 focus groups between May and July 2006. There were three focus groups in each of our four study counties: one each for farmers, nonfarming rural dwellers, and city dwellers. Additional focus groups brought together conservationists, developers, and Spanish-speaking farm workers. Altogether, 133 people participated in the focus groups. Major findings from the focus groups include:

- Widespread agreement that farmland provides significant contributions to western North Carolina communities.

- Strong support for farmland's ecological, scenic, and cultural contributions.
- Feelings of inability to stop the changes to the landscape that participants witness in their communities.

- Varying levels of importance of farm-level prosperity relative to other farmland characteristics. Farm prosperity was deemed more important by those more closely connected with agriculture.

Themes identified in the focus groups were used to finalize the design of the FVP survey; to provide continuity we also adopted some of the descriptions and phrases used by focus group participants in key survey questions. In the questionnaire we asked respondents about their impressions of farmland, the benefits and costs that it provides their community, their opinions about land use change and government action to protect farmland, and their willingness to pay to protect farmland in the region.

Because we surmised that both residents and visitors value the region's farmland, the FVP survey queried both groups. The resident survey was mailed to a random sample of 3,200 households in November 2007; a single-use, passwordprotected version of the questionnaire was available online for respondents who preferred to complete it via their home computer. Following Dillman, Smyth, and Christian (2009), a reminder postcard and follow-up mailing were sent to addresses that did not respond to the first mailing. The visitor survey was conducted at various local festivals, visitor centers, and popular tourist sites between September and November 2007; an invitation to complete the survey also appeared in the Asheville Convention and Visitor Bureau's visitor newsletter.

A total of 1,243 responses to the FVP survey were collected from 936 residents and 307 visitors. Our solicitation of visitors at festivals and other sites yielded both resident and nonresident respondents. We found the resident responses collected as part of this convenience sample were statistically significantly different from those collected from 
Table 2. Demographic Characteristics of Survey Respondents

\begin{tabular}{lcc}
\hline & Resident Respondents & Visitor Respondents \\
\hline Average age & 60 years & 52 years \\
\hline Gender (\% female) & $51 \%$ female & $69 \%$ female \\
\hline Full-time residents & $89 \%$ & $n / a$ \\
\hline Years living in the county [visiting the region] & 35 years & 15 years \\
\hline $\begin{array}{l}\text { Education (\% BA or higher) } \\
\begin{array}{l}\text { Purchase local farm products regularly (once a week or } \\
\text { more) [on this trip] }\end{array}\end{array}$ & $53 \%$ & $70 \%$ \\
\hline
\end{tabular}

a Questions for visitors were reworded slightly from those asked of residents to ensure that their responses reflected their preferences for farmland in Western North Carolina (as opposed to farmland in their home region). Changes are noted in brackets.

n/a: Question was not asked of visitor respondents.

Table 3. Responses to the question, "When you think of farmland, what do you think of?"

\begin{tabular}{lcc}
\hline & Resident & Visitor \\
\hline$n^{a}$ & 762 & 280 \\
\hline Pasture & $88.8 \%$ & $88.9 \%$ \\
\hline Farm animals & 87.3 & 87.5 \\
\hline Cropland & 81.5 & 76.8 \\
\hline Farm buildings \& equipment & 79.9 & 84.3 \\
\hline Hay fields & 79.1 & 73.2 \\
\hline Open space & 77.4 & 78.6 \\
\hline Food & 74.7 & 77.1 \\
\hline Orchards & 63.6 & 70.4 \\
\hline Independent way of life & 61.3 & 61.4 \\
\hline Woodland & 58.8 & 48.9 \\
\hline Small-scale vegetable and flower & 58.1 & 50.0 \\
gardens & & \\
\hline Close-knit rural community & 55.2 & 61.1 \\
\hline Soil & 54.2 & 62.5 \\
\hline Family ties & 53.7 & 63.2 \\
\hline Wildflowers & 50.1 & 49.3 \\
\hline Traditional homes or buildings & 44.5 & 50.4 \\
\hline Historic landmarks & 26.2 & 26.4 \\
\hline Oiber, such as cotton or wool & 14.0 & 25.0 \\
\hline
\end{tabular}

Note: The question responses are re-ordered so that responses are listed according to popularity.

a Because of item nonresponse, the sample size for each question varies slightly; thus $n$ is reported in each table. the random sample of residents. To simplify discussion, in this paper we report on the 1,079 responses collected from the random sample of residents $(\mathrm{n}=772)$ and visitors $(\mathrm{n}=307)$.

\section{Results}

Table 2 provides an overview of respondent demographics. Our sample had higher education levels than do typical residents of the region and, because we restricted our survey to adults, the average respondent was older than the region's average age. Most respondents were long-term residents (averaging 35 years) or visitors who had been returning to the area over a long period (averaging 15 years), indicating that our sample is very familiar with the region.

\section{Identification of the Multiple Benefits of Farmland}

We began the survey with a question designed to get respondents thinking about farmland in general. We asked, When you think of farmland, what do you think of? and found that the physical characteristics of farmland were most frequently selected from the categories provided. Pasture, farm animals, cropland, farm buildings and equipment, hay fields, open space, and food were all mentioned by at least $70 \%$ of all respondents (table 3). The less tangible features that may be conjured up when thinking of farmland - an independent way of life, close-knit rural communities, or family ties - were selected by at least half of all respondents. 
When asked about the benefits of farmland, survey respondents indicated a clear understanding of the multiple benefits that farmland provides to their communities (table 4). The most frequently selected benefit for both resident and visitor respondents was locally produced food (identified by $92 \%$ of residents and $98 \%$ of visitors), which is consistent with the strong local food movement in the region. Other benefits recognized by at least $75 \%$ of both resident and visitor respondents include scenic beauty, jobs for farmers and others in agriculture, agricultural heritage, and open space. Thus a majority of survey respondents identify the local food, economic, aesthetic, heritage, and open space functions of agricultural lands.

Table 4. Responses to the question, "What benefits, if any, do you believe farmland brings to your county [to Western North Carolina]?"

\begin{tabular}{|c|c|c|}
\hline & Resident & Visitor \\
\hline$n^{a}$ & 764 & 276 \\
\hline Locally produced food & $92.3 \%$ & $97.8 \%$ \\
\hline Scenic beauty & 80.6 & 89.5 \\
\hline $\begin{array}{l}\text { Jobs for farmers and their } \\
\text { suppliers, pickers, packers, } \\
\text { and truck drivers }\end{array}$ & 80.1 & 89.9 \\
\hline Agricultural heritage & 79.8 & 89.9 \\
\hline Open space & 74.9 & 76.4 \\
\hline Wildlife habitat & 74.7 & 71.4 \\
\hline Soil conservation & 60.7 & 72.5 \\
\hline Attractiveness to visitors & 56.9 & 79.7 \\
\hline $\begin{array}{l}\text { Opportunity to observe natural } \\
\text { cycles }\end{array}$ & 54.1 & 62.3 \\
\hline Biodiversity & 41.2 & 67.8 \\
\hline $\begin{array}{l}\text { Capacity to slow global climate } \\
\text { change }\end{array}$ & 40.7 & 56.9 \\
\hline Flood control & 37.6 & 44.2 \\
\hline Other & 8.5 & 9.1 \\
\hline $\begin{array}{l}\text { None: I do not believe } \\
\text { farmland benefits my county } \\
\text { [Western North Carolina] }\end{array}$ & 0.4 & 0.0 \\
\hline$\%$ no response & 1.0 & 10.1 \\
\hline
\end{tabular}

Note: The question responses are re-ordered so that responses are listed according to popularity.

a Because of item nonresponse, the sample size for each question varies slightly; thus $n$ is reported in each table.
While the primary focus of our study was on the perceived benefits that farmland provides, we also asked respondents about their impression of the costs that farmland imposes on their county. The most frequent response for residents was $I$ do not believe farmland imposes costs on my county (51.6\%), and environmental damage was the cost most frequently noted by visitors ( $53.5 \%$; table 5$)$. Costs often associated with farmland in other parts of the country, such as dust and smells, were indicated by less than $10 \%$ of residents. This is likely because the topography of the region leads to relatively small-scale agricultural enterprises with very little row-crop cultivation and few livestock operations of significant size.

Table 5. Responses to the question, "What costs, if any, do you believe farmland brings to your county [to Western North Carolina]?"

\begin{tabular}{lcc}
\hline & Resident & Visitor \\
\hline$n^{a}$ & 746 & 273 \\
\hline $\begin{array}{l}\text { None: I do not believe farmland } \\
\text { imposes costs on my county }\end{array}$ & $51.6 \%$ & $43.6 \%$ \\
[Western North Carolina] & & \\
\hline Environmental damage & 42.5 & 53.5 \\
\hline Nutrient and/or pesticide runoff & 36.9 & 47.6 \\
\hline Soil erosion & 14.2 & 17.2 \\
\hline Wildlife habitat loss & 12.2 & 18.7 \\
\hline Smells & 9.4 & 11.0 \\
\hline Dust & 6.2 & 10.3 \\
\hline $\begin{array}{l}\text { Traffic congestion caused by } \\
\text { slow-moving farm vehicles }\end{array}$ & 5.9 & 7.0 \\
\hline Reduced flood control & 5.0 & 5.9 \\
\hline $\begin{array}{l}\text { Prevents profitable new } \\
\text { development }\end{array}$ & 3.2 & 4.4 \\
\hline Other & 2.9 & 2.2 \\
\hline Biodiversity loss & 2.5 & 11.7 \\
\hline Noise & 2.1 & 4.0 \\
\hline Contribution to global warming & 1.5 & 4.8 \\
\hline Other environmental damage & 1.1 & 1.1 \\
\hline
\end{tabular}

Note: The question responses are re-ordered so that responses are listed according to popularity.

a Because of item nonresponse, the sample size for each question varies slightly; thus $n$ is reported in each table. 
In addition to knowing respondents' perceived benefits and costs of farmland, we were also interested in learning how they feel farmland directly affects their lives. We thus asked them to identify whether and how farmland affects their lives. Once again, the most popular response was related to local food, while scenic beauty was the second most frequent response (table 6).

Respondents' third choice - I am bappy just to know it is there - suggests that the existence of farmland provides intangible psychological benefits to most respondents.

Table 6. Responses to the question, "How does farmland affect your quality of life?"

\begin{tabular}{lcc}
\hline & Resident & Visitor \\
\hline$n^{a}$ & 761 & 273 \\
\hline $\begin{array}{l}\text { Farmland allows me to buy local } \\
\text { food }\end{array}$ & $85.8 \%$ & $90.8 \%$ \\
\hline $\begin{array}{l}\text { Farmland is attractive and makes } \\
\text { the area more beautiful }\end{array}$ & 84.5 & 80.6 \\
\hline $\begin{array}{l}\text { I am happy just to know that it is } \\
\text { there }\end{array}$ & 82.0 & 76.6 \\
\hline $\begin{array}{l}\text { Farmland provides recreation } \\
\text { Farmland provides a link to my } \\
\text { agricultural heritage }\end{array}$ & 56.2 & 68.5 \\
\hline $\begin{array}{l}\text { Farmland helps me to learn about } \\
\text { natural cycles }\end{array}$ & 38.5 & 53.1 \\
\hline $\begin{array}{l}\text { Farmland brings visitors to the } \\
\text { area, which helps my county tax } \\
\text { base }\end{array}$ & 33.9 & $\mathrm{n} / \mathrm{a}$ \\
\hline $\begin{array}{l}\text { Farmland brings visitors to the } \\
\text { area, which helps the business or } \\
\text { industry I am in }\end{array}$ & 28.4 & $\mathrm{n} / \mathrm{a}$ \\
\hline $\begin{array}{l}\text { Unproductive farmland prevents } \\
\text { new economic development }\end{array}$ & 5.7 & 8.4 \\
\hline $\begin{array}{l}\text { Pollution and byproducts from } \\
\text { farmlands pose threats to my } \\
\text { health }\end{array}$ & 4.3 & 7.7 \\
\hline $\begin{array}{l}\text { Other } \\
\text { Farmland does not affect my }\end{array}$ & 2.5 \\
\hline \begin{tabular}{l} 
quality of life \\
\hline
\end{tabular} & & 2.4 \\
\hline
\end{tabular}

Note: The question responses are re-ordered so that responses are listed according to popularity.

a Because of item nonresponse, the sample size for each question varies slightly; thus $n$ is reported in each table. n/a: Question was not asked of visitor respondents.
When asked to rank statements about farmland in order of importance, residents and visitors again expressed similar, although not identical, views. The most important characteristic was local food provision, followed by farm income and scenic beauty (table 7). These responses corroborate the implicit ranking provided by responses to earlier questions.

To determine the consistency of responses, we asked respondents to identify which farmland characteristics were the most important to them in a series of questions designed to give them time to reflect on the characteristic. Specifically, this set of questions asked participants to rate each characteristic on a seven-point Likert scale based on whether the characteristic was important to them; some characteristics had positive connotations ("visual appeal") while others had negative connotations ("unpleasant smells"). A comparison of the average ratings (table 8) suggests that contribution to environmental quality is very important -

Table 7. Average Ranking of Statements Related to Important Farmland Characteristics (1 = most important, 7 = least important)

\begin{tabular}{lcc}
\hline & Resident & Visitor \\
\hline$n^{a}$ & 687 & 244 \\
\hline Farmland provides local food & 2.2 & 1.9 \\
\hline $\begin{array}{l}\text { Farmland provides income for } \\
\text { farmers }\end{array}$ & 2.5 & 2.5 \\
\hline $\begin{array}{l}\text { Farmland provides scenic } \\
\text { beauty }\end{array}$ & 3.7 & 4.1 \\
\hline $\begin{array}{l}\text { Farmland provides habitat for } \\
\text { wildlife }\end{array}$ & 4.0 & 4.0 \\
\hline $\begin{array}{l}\text { Farmland contributes to our } \\
\text { region's agricultural heritage }\end{array}$ & 4.4 & 4.5 \\
\hline $\begin{array}{l}\text { Farmland provides other } \\
\text { natural services like } \\
\text { biodiversity and pollination }\end{array}$ & 4.6 & 4.1 \\
\hline $\begin{array}{l}\text { Farmland provides flood } \\
\text { control }\end{array}$ & 5.3 & 5.1 \\
\hline
\end{tabular}

Note: The question responses are re-ordered so that responses are listed according to their ranking.

a Because of item nonresponse, the sample size for each question varies slightly; thus $n$ is reported in each table. 
something that doesn't clearly show up in the responses to earlier questions. The remaining average score comparisons demonstrate similarities to responses to earlier questions underlining the importance of farmland for local food, visual appeal, and rural character.

\section{Stated Willingness to Pay Farmland Protection}

In the second section of the survey we used a contingent valuation question to ask respondents about their willingness to contribute to farmland protection in the study region. Contingent valuation is a nonmarket valuation method that asks respondents a hypothetical question regarding their willingness to pay for goods or services that are not typically exchanged in markets. Because the study region uses multiple methods to protect farmland (including land purchase and conservation easements), our question asked respondents generally about their willingness to make voluntary annual donations if they knew the money would be designated for protecting farmland in their county (or western North Carolina, if they were not residents). The question was designed using standard contingent valuation techniques, which include a realistic payment vehicle (a voluntary donation), a range of randomized bids (USD25, USD50, USD100, USD200, USD250, USD500, USD1,000), and a dichotomous choice (yes/no) format. Over half of resident respondents $(54.3 \%)$ and two-thirds of visitor respondents $(66.7 \%)$ indicated that they were willing to make some contribution to protect farmland in their community (table 9). Using standard regression methods, average annual willingness to pay was estimated at USD184.64 for residents and USD195.41 for visitors, yielding a combined sample estimate of USD184.79. Significant factors influencing willingness to pay included resident status, income, education level, the dollar amount presented in the question, and whether the
Table 8. Importance of Various Farmland

Characteristics $(1=$ not important, 7 = very important; average score reported)a

\begin{tabular}{lcc}
\hline & Resident & Visitor \\
\hline $\begin{array}{l}\text { Contribution to environmental } \\
\text { quality }\end{array}$ & 6.3 & 6.3 \\
\hline Availability of local farm products & 6.2 & 6.4 \\
\hline Visual appeal & 6.0 & 5.9 \\
\hline Rural character & 5.8 & 5.8 \\
\hline Pleasant smells/aroma & 5.2 & 5.0 \\
\hline Impacts on water quality & 4.8 & 5.2 \\
\hline Impacts on air quality & 3.8 & 4.5 \\
\hline Unpleasant smells & 3.1 & 3.5 \\
\hline
\end{tabular}

Note: The question responses are re-ordered so that responses are listed according to their ranking.

a Sample size and \% no response vary by item. Complete results can be viewed at

http://www2.unca.edu/farmlandvalues/pdfs/survey results.pdf

respondent indicated a willingness to pay more for local food (Mathews, 2009). Most of those willing to make a voluntary donation indicated they would prefer that a local nonprofit organization manage the funds $(80 \%$ of resident sample, $75.7 \%$ of visitor sample) rather than a local, state, or federal government entity.

Given the interest in local food in the region, we also asked respondents if they would be willing to pay more for their food if the increase in price
Table 9. Willingness to Pay for Farmland Protection and Preferred Fund Management (all currency in USD)

\begin{tabular}{lcc}
\hline & Resident & Visitor \\
\hline$n^{a}$ & 732 & 263 \\
\hline Respondents willing to make a contribution $>\$ 0$ & $54.3 \%$ & $66.9 \%$ \\
\hline$\%$ no response & 1.9 & 13.0 \\
\hline$n^{a}$ & 280 & 103 \\
\hline $\begin{array}{l}\text { Estimated average annual voluntary contribution } \\
\text { for farmland protection }\end{array}$ & $\$ 184.64$ & $\$ 195.41$ \\
\hline $\begin{array}{l}\text { Prefer to have funds managed by local nonprofit } \\
\text { organization }\end{array}$ & $80 \%$ & $75.7 \%$ \\
\hline$\%$ no response & 4.9 & 1.9 \\
\hline
\end{tabular}

a Because of item nonresponse, the sample size for each question varies slightly; thus $n$ is reported for each question. 


\section{Table 10. Willingness to Pay More for Food and Reasons for Not Doing So}

\begin{tabular}{|c|c|c|}
\hline & Resident & Visitor \\
\hline$n^{a}$ & 745 & 256 \\
\hline $\begin{array}{l}\text { Respondents willing to pay more for food if the increase went to protect farmland in their } \\
\text { county [WNC] }\end{array}$ & $63.9 \%$ & $87.9 \%$ \\
\hline$\%$ no response & 3.5 & 16.6 \\
\hline \multicolumn{3}{|l|}{ Reasons for not indicating a willingness to pay more for food } \\
\hline$n^{a}$ & 265 & 32 \\
\hline I do not want to pay any more for my food & $53.2 \%$ & $43.8 \%$ \\
\hline I should not have to pay to preserve farmland & 37.4 & 12.5 \\
\hline I do not have sufficient income to pay more for my food & 32.8 & 9.4 \\
\hline I do not believe farmland will be preserved, regardless of my payment & 29.1 & 15.6 \\
\hline $\begin{array}{l}\text { I would prefer to make a voluntary contribution on my local taxes rather than food prices } \\
\text { to fund farmland protection }\end{array}$ & 16.2 & 12.5 \\
\hline I do not have enough information to decide right now & 7.9 & 6.3 \\
\hline I do not believe preserving farmland will benefit me & 3.8 & 0.0 \\
\hline Other & 3.8 & 12.5 \\
\hline $\begin{array}{l}\text { I do not think that the amount of farmland acreage will decrease, so I do not think we } \\
\text { need to preserve it }\end{array}$ & 1.1 & 0.0 \\
\hline Farmland in Western North Carolina is not that important to me & 0.8 & 0.0 \\
\hline$\%$ no response & 5.6 & 0.0 \\
\hline
\end{tabular}

Note: The question responses are re-ordered so that responses are listed according to popularity.

a Because of item nonresponse, the sample size for each question varies slightly; thus $n$ is reported for each question.

went directly to protect farmland in their county [or western North Carolina]. Not surprisingly, a majority of both residents $(63.9 \%)$ and visitors $(87.9 \%)$ indicated they would be willing to do so (table 10). ${ }^{1}$ We did not ask specifically about how much more they would be willing to pay for their food, but did ask for an explanation from those who replied No. The analysis of $N o$ responses provides some interesting insight into our sample. As one might expect, most of those who did not wish to support a food price increase to protect farmland indicated that they did not want to pay more for their food $(53.2 \%$ of residents, $43.8 \%$ visitors). However, the second most popular response for residents, selected by over one-third

\footnotetext{
${ }^{1}$ A survey of visitors to downtown Asheville conducted in 2010 confirms this result: $81 \%$ of residents and $85 \%$ of visitors polled indicated they would be willing to pay more for their food if the price increase went directly to protect farmland in western North Carolina (Riddle, 2011).
}

of the resident respondents who said they were not willing to pay more for their food to protect farmland, indicated I should not have to pay to protect farmland (37.4\% or 99 resident responses). This suggests that a small but significant portion of our sample $(13 \%)$ does not feel responsibility for footing the bill for farmland protection.

\section{Concerns about Farmland Conversion}

The above results indicating a willingness to pay for farmland protection are consistent with the concerns delineated by respondents in the final section of our survey. Respondents were asked to indicate their level of agreement with a series of statements including I believe the community needs to do more to protect farmland (54\% and $46.1 \%$ indicate they strongly agree (SA)) and I am concerned about the likelihood that farmland will be developed (62.2\% SA resident; 58.4\% SA visitor; table 11). The concern about farmland loss is not surprising from a sample where one-third believe that our region should supply 
its own basic food needs locally, including the energy and material inputs needed to produce the food (36.8\% SA resident; $36.2 \%$ SA visitor). Most respondents believe that private decisions often impact others in the community (56.0\% SA resident; $67.2 \% \mathrm{SA}$ visitor). However, there was less support for the belief that more government action is needed (17.6\% SA resident; $14.5 \% \mathrm{SA}$ visitor).

\section{Discussion and Implications}

Participants in the FVP recognize and articulate the multiple functions of agriculture. A majority of respondents identify local food provisioning, economic, aesthetic, heritage, and open space functions of agricultural lands in four western North Carolina counties. Many of the most popular benefits (local food, aesthetic, heritage) require an active agriculture in the region to be sustained. Recognition of these characteristics, along with stated concern about loss of farmland and willingness to pay to protect farmland by both residents and visitors, suggest a commitment to MFA and a desire to

Table 11. Opinions about Farmland and Land Use Issues $(1=$ Strongly Disagree, 7 = Strongly Agree)

\begin{tabular}{|c|c|c|c|}
\hline & & Resident & Visitor \\
\hline \multirow{5}{*}{$\begin{array}{c}\text { "I am concerned about the likelihood } \\
\text { that farmland in my county [in } \\
\text { western North Carolina] will be } \\
\text { developed for nonfarm use." }\end{array}$} & \% Strongly agree ( 7 on Likert scale) & $62.2 \%$ & $58.4 \%$ \\
\hline & Average score & 6.2 & 6.3 \\
\hline & Median score & 7 & 7 \\
\hline & $n$ & 754 & 257 \\
\hline & $\%$ no response & $2.3 \%$ & $16.3 \%$ \\
\hline \multirow{5}{*}{$\begin{array}{l}\text { "I believe the community needs to do } \\
\text { more to protect farmland." }\end{array}$} & \% Strongly agree (7 on Likert scale) & $54.0 \%$ & $46.1 \%$ \\
\hline & Average score & 6.1 & 6.1 \\
\hline & Median score & 7 & 7 \\
\hline & $n$ & 756 & 256 \\
\hline & $\%$ no response & $2.1 \%$ & $16.6 \%$ \\
\hline \multirow{5}{*}{$\begin{array}{l}\text { "I believe that our region [western } \\
\text { North Carolina] should supply its own } \\
\text { basic food needs locally, including the } \\
\text { energy and material inputs needed to } \\
\text { produce the food." }\end{array}$} & \% Strongly agree ( 7 on Likert scale) & $36.8 \%$ & $36.2 \%$ \\
\hline & Average Score & 5.6 & 5.8 \\
\hline & Median Score & 6 & 6 \\
\hline & $\bar{n}$ & 748 & 257 \\
\hline & $\%$ no response & $3.1 \%$ & $16.3 \%$ \\
\hline \multirow{5}{*}{$\begin{array}{l}\text { "What do you think about the impacts } \\
\text { of private land use decisions in your } \\
\text { community?" }\end{array}$} & $\begin{array}{l}\text { \% Private decisions often impact others in } \\
\text { the community ( } 7 \text { on Likert scale) }\end{array}$ & $56.0 \%$ & $67.2 \%$ \\
\hline & Average score & 6.3 & 6.5 \\
\hline & Median score & 7 & 7 \\
\hline & $\bar{n}$ & 747 & 256 \\
\hline & $\%$ no response & $3.2 \%$ & $16.6 \%$ \\
\hline \multirow{5}{*}{$\begin{array}{c}\text { "What do you think about the level of } \\
\text { local government involvement in land } \\
\text { use in your county [in western North } \\
\text { Carolina]?" }\end{array}$} & $\begin{array}{l}\% \text { More government action is needed ( } 7 \text { on } \\
\text { Likert scale) }\end{array}$ & $17.6 \%$ & $14.5 \%$ \\
\hline & Average score & 4.3 & 4.8 \\
\hline & Median score & 4 & 5 \\
\hline & $\bar{n}$ & 738 & 256 \\
\hline & $\%$ no response & 4.4 & 16.6 \\
\hline
\end{tabular}

a The statement corresponding to (1) on the Likert scale was: Private decisions never impact others in the community. ${ }^{\mathrm{b}}$ The statement corresponding to (1) on the Likert scale was: Less government action is needed. 
see it maintained. Most residents responding to our survey had not participated in a forum, public meeting, or survey related to land use in the community in the year prior to our survey $(88 \%)$, which suggested that we captured the preferences of citizens with an interest in farmland who were not active in land use issues.

\section{Policy Implications}

Because farmers are not typically compensated for the benefits agriculture provides to the surrounding region, such as scenic amenities and contributions to cultural heritage, agriculture represents a potential source of market failure. Hediger and Lehmann note that "multifunctionality could provide an efficiency-based argument for government support to agriculture" (2003; p. 1127). This study documented that people throughout the region believe that farmland provides them benefits. If future studies demonstrate widespread concurrence with these results, public financing to protect farmland could be justified. Buncombe County already uses its general fund to support land conservation (including farmland); since 2001 more than USD5.5 million has been designated to assist land protection efforts yielding over 3,800 protected acres (1,538 hectares) (Buncombe Land Conservation Advisory Board, 2010; D. Truempy, personal communication, May 9, 2011). Counties could consider means to provide farmers with compensation for the ways that their citizens value and feel that they benefit from farmland.

As it is not likely that local government budgets yield sufficient funds to compensate all farmers for all benefits they provide to their communities, county government officials could consider a competitive fund that would offer compensation in the form of additional tax credits or payments to farmers who meet specific criteria similar to the Natural Resource Conservation Service's (NRCS) Environmental Quality Incentives Program (EQIP) and Wildlife Habitat Incentives Program (WHIP). For example, the significant interest in local food expressed by respondents in the region suggests a community priority for efforts that focus on the most productive agricultural lands in order to protect food production capabilities. Study results also suggest that the role of farmland in providing scenic quality and cultural heritage amenities should receive expanded recognition. When farmland is developed, the community loses these important amenities. Impact fees could be imposed on development to compensate the community for the loss of these assets.

\section{Visitor Preferences for $M F A$}

It is significant for four reasons that visitors recognize the benefits of the region's multifunctional agriculture. First, it reinforces the fact that our local food and agriculture system is not a closed system. Most food system advocates recognize that local systems rely on imports of things like seed, livestock, fuel, and equipment from other areas for production to take place; systems typically export food and fiber products. This research supports the idea that local agricultural systems also provide nonfood exports in the form of tourism benefits. Because these exports are not priced like most agricultural products, farmers are not financially benefiting from the aesthetic and other benefits provided to visitors.

Second, the fact that visitors to a region can experience a familiarity with the landscape and its elements without living there suggests the area is offering desired and appreciated tourism experiences. This is significant because unlike the Amish region of Pennsylvania or Napa Valley of California, there is no coordinated marketing plan for agricultural tourism in western North Carolina. This suggests opportunities for individual farms and tourism development authorities to expand their efforts to attract visitors seeking this type of experience.

Third, because the study documents that tourists value the region's farmland and derive significant benefits from it, visitors to the region should be included as potential sources of revenue for farmland protection. Specific ideas for doing so are included in the following section.

Fourth, because visitors express preferences similar to those of residents, efforts to protect what is important to residents will have benefits for visitors and vice versa. In other words, agricultural 
land protection could serve to promote tourism development (or maintenance) for the region. Thus local tourism development authorities should be solicited as partners in local farmland protection to maintain the region's investment in tourism. In the study region, Buncombe and Haywood counties have tourism development authorities that generate revenue from a hotel occupancy tax; in addition to marketing the region's tourist amenities, these funds also contribute to projects that generate additional room nights such as parks, music venues, and museums (Shrestha, 2010). Since farmland attracts tourists, land protection could also be included in the list of eligible spending categories.

\section{Financing Farmland Protection}

As mentioned earlier, tailgate markets and CSA enterprises are popular in western North Carolina; local food's ranking as the most frequently cited benefit of farmland in this study supports their value to respondents. The fact that respondents both indicate they think private decisions impact others and state a desire for more government action on farmland protection issues suggests a collective action framework. However, participants in this study report they do not want government to be in charge of a farmland protection fund financed by their donations. The recognition of MFA by both residents and visitors thus suggests the need for additional tools for capturing the value that farmers provide for the many nonfood benefits that are simultaneously produced with agriculture.

To capture a greater amount of both visitor and resident dollars to protect farmland, a program could be created that asks restaurant operators to invite diners to round-up their total or add a donation to their bill that would go to a local nonprofit farmland protection fund. Given that over 120 restaurants in the region actively support the local food movement (ASAP, 2010), it might not be difficult for such a program to gain momentum in the region.

Another tool could target those who particularly value the scenic quality amenities associated with farmland by providing a mechanism to compensate farmers for the scenic beauty their land and agricultural practices provide. While there are likely thousands of parcels that could qualify as "scenic" in this region, to make the program manageable the program could target lands within the Blue Ridge Parkway viewshed and other designated scenic byways popular with tourists, or those within the viewsheds of homes whose real estate listings mention scenic views. After placing brochures in hotel rooms or at rental car counters, visitors could be asked at check-out if they would be willing to make a donation to protect the scenic beauty of the region by protecting farmland, and businesses could be asked to match their customers' contributions. Since respondents clearly indicated a preference for nonprofit coordination of donated funds, a local nonprofit could be designated to collect donations to finance the protection of cultural assets and heritage practices. While the economic feasibility of these ideas needs further research, it is clear that there are many opportunities for creative financing for farmland protection policies that could work in this region.

\section{Application to Other Regions}

While these specific results and recommendations may not be directly transferable, there are several ways that this research can be useful to other regions. First, it provides a model for how to engage communities in the process of inventorying the many benefits that agriculture provides. The methods used here emphasize a "from the ground up" approach to identifying the benefits of MFA. The precise portfolio of benefits will likely look different in other parts of the country or have different relative levels of importance than in western North Carolina. For example, the benefits that people derive from farmland that is predominantly pasture may differ significantly from the benefits they perceive from tilled land. The pattern of farmland - whether there are large areas of contiguous farmland or if housing or other visual intrusions are present - may also affect the perceived scenic amenities associated with farmland (Irwin et al., 2003). Future research should collate and compare the benefits of MFA that accrue in different geographic regions so we 
can learn how space and place affect demand for MFA in the U.S. Because of the United States' diversity in agriculture and extensive geographic footprint, the demand for MFA is likely to look different than what the literature currently documents.

Second, agricultural regions without a developed agritourism sector should be interested to learn that agricultural lands can play a significant role in tourism development even when agritourism itself is not developed. An inventory such as the FVP that makes the invisible functions of agriculture more visible can help decision-makers better understand the role natural resources play in economic development, perhaps leading to new marketing opportunities.

A third way that this research may be helpful to other regions is by providing a portfolio of ideas for engaging stakeholder groups in farmland preservation efforts. Whether the goal is to raise funds to finance farm protection or to engage citizens and policy-makers in the process of prioritizing tracts for consideration in a community's farmland protection plan, it is useful to know which messages resonate among diverse citizen groups in a community.

Knickel, Kröger, Bruckheimer, and Engwall (2009) call for better links between qualitative and quantitative methods of evaluation as well as improved data on multiple functions that go beyond production statistics. Thus a final way that our study can be applied to other regions is through recognizing how various types of data can be used to inform local policy and evaluation. For example, our method of focus groups, surveys, and PGIS techniques could be replicated in the same five-year intervals as the Census of Agriculture, thus providing qualitative data on the perceptions and preferences of community members that would align with the quantitative data provided by the census. Over time, this would allow community members and officials to determine how perceptions of agriculture change along with the changing practices of agriculture. Research-based policy decisions could be implemented to improve both efficiency of policy actions and community outcomes.

\section{Limitations and Suggestions for Future Research}

There are three limitations of the method described in this research. First, the techniques used in this project require financial and time commitments that are not readily available in many communities. Second, because of the time commitment required of participants to meaningfully engage in the process (either by attending a focus group or PGIS session, or completing a detailed questionnaire in a survey), many individuals will not participate. Those who are most interested in the MFA are also those who are most willing to take the time to participate. While the engagement of stakeholders is essential to effective research, this self-selection can lead to biased results if the self-selected participants are not representative of stakeholder groups. Future research could address these issues by refining the method so that its replicability is streamlined and participant time commitment is minimized while also ensuring representative participation from stakeholder groups.

A final shortcoming of the method outlined here is that, like most research, it is static; it provides a baseline inventory of the benefits of a region's MFA. With changes in farm operation, land use, and population, it is likely that the portfolio of benefits provided by MFA will also change. Research to inventory the benefits should be replicated at regular intervals to ensure continued compatibility with community preferences. This longitudinal effort to link community input with outcomes would be similar to the successful Census-Based Impact-Oriented (CBIO) Approach used in developing countries to monitor and direct public health expenditures (Perry, Robison, Chavez, Taja, Hillari, Shanklin, \& Wyon, 1999). Regular inventories would allow us to monitor over time the benefits of MFA as well as the effectiveness of farmland policies designed to protect these benefits. 


\section{Conclusion}

Recognizing agriculture's multifunctionality serves several objectives. First, it allows community members and local decision-makers to better understand their community's assets. Second, it can help policy-makers identify sources of market failure and potential remedies for those failures, such as ways to compensate farmers for the unpriced services they provide to communities. Finding a way to compensate farmers for the currently unremunerated functions of agricultural lands can help keep land in farms. Third, MFA may contribute to the sustainable development of rural areas if it promotes efficient resource allocation (Garrod et al., 2006; Hediger \& Knickel, 2009).

This research demonstrates a method for communities to inventory the multiple functions of agriculture. Results suggest that a portfolio approach is necessary to understand and sustain local agricultural economies; this reflects the portfolio of agricultural values (and assets) that we hold. Expanded use of community-based methods for documenting agriculture's multiple functions will lead to an improved understanding of U.S. agriculture and provide opportunities for effective monitoring and assessment of agricultural and land-use policies.

\section{References}

Appalachian Sustainable Agriculture Project (ASAP). (2010). Local food guide 2010-2011. Retrieved from http://www.asapconnections.org/localfoodguide. $\underline{\mathrm{html}}$

Bergstrom, J. C., Dillman, B. L., \& Stoll, J. R. (1985). Public environmental amenity benefits of private land: The case of prime agricultural land. Southern Journal of Agricultural Economics, 17(1), 139-149.

Bergstrom, J. C., \& Ready, R. C. (2009). What have we learned from over 20 years of farmland amenity valuation research in North America? Applied Economic Perspectives and Policy, 31(1), 21-49. http://dx.doi.org/10.1111/j.14679353.2008.01424.x

Blue Ridge Forever. (2009). Blue Ridge Forever Focus Areas. Retrieved from http://www.blueridgeforever.info/ sites/default/ files/pdf/CVFocusAreaFactSheetsAll.pdf
Boisvert, R. N. (2001). A note on the concept of jointness in production. In OECD, Multifunctionality: Toward an Analytical Framework (pp. 114-134). Paris: OECD Publications Service.

Bromley, D. W., \& Hodge, I. (1990). Private property rights and presumptive policy entitlements: Reconsidering the premises of rural policy. European Review of Agricultural Economics, 17, 197-214. http://dx.doi.org/10.1093/erae/17.2.197

Buckley, C., van Rensburg, T. M., \& Hynes, S. (2009). Recreational demand for farm commonage in Ireland: A contingent valuation assessment. Land Use Policy, 26, 846-854. http://dx.doi.org/10.1016/ j.landusepol.2008.10.013

Buncombe County Tourism Development Authority. (2009). Welcome to the world's first foodtopian society.

Retrieved December 10, 2010, from http://www.exploreasheville.com/foodtopia

Daugstad, K., Rønningen, K., \& Skar, B. (2006). Agriculture as an upholder of cultural heritage? Conceptualizations and value judgments - A Norwegian perspective in international context. Journal of Rural Studies, 22(1), 67-81. http://dx.doi.org/10.1016/j.jrurstud.2005.06.002

Dillman, D., Smyth, J. D., \& Christian, L. M. (2009). Internet, mail and mixed mode surveys: The tailored dsign method. Hoboken, N.J.: John Wiley \& Sons.

Drake, L. (1992). The non-market value of the Swedish agricultural landscape. European Review of Agricultural Economics, 19(3), 351-364. http://dx.doi.org/10.1093/erae/19.3.351

Duke, J. M., \& Aull-Hyde, R. (2002). Identifying public preferences for land preservation using the analytic hierarchy process, Ecological Economics, 42(1-2), 131-145. http://dx.doi.org/10.1016/S0921$\underline{\text { 8009(02)00053-8 }}$

European Commission. (2004). European Union Citizens and Agriculture from 1995 to 2003. Special Eurobarameter. Brussels: European Opinion Research Group EEIG.

Evans, M., Davé, D., Stoddard, J., \& Ha, I. (2006). Measurement of the economic vitality of the Blue Ridge National Heritage Area. Section III: An analysis of secondary data and economic impact. Retrieved from http://heritagearearesources.com/PDF/ brnhareptsec3.pdf 
Gardner, B. D. (1977). The economics of agricultural land preservation. American Journal of Agricultural Economics, 59(5), 1027-1036. http://dx.doi.org/10.2307/1239883

Garrod, B., Wornell, R., \& Youell, R. (2006). Reconceptualising rural resources as countryside capital: The case of rural tourism. Journal of Rural Studies, 22(1), 117-128. http://dx.doi.org/10.1016/j.jrurstud.2005.08.001

Hall, C., McVittie, A., \& Moran, D. (2004). What does the public want from agriculture and the countryside? A review of evidence and methods. Journal of Rural Studies, 20(2), 211-225. http://dx.doi.org/10.1016/j.jrurstud.2003.08.004

Hediger, W., \& Knickel, K. (2009). Multifunctionality and sustainability of agriculture and rural areas: A welfare economics perspective. Journal of Environmental Policy \& Planning, 11(4), 291-313. http://dx.doi.org/10.1080/15239080903412453

Hediger, W., \& Lehmann, B. (2003). Multifunctional agriculture and the preservation of environmental benefits. Proceedings of the $25^{\text {th }}$ International Conference of Agricultural Economists (LAAE), 1127-1135.

Hellerstein, D. (2002). Farmland protection programs: What does the public want? USDA Economic Research Service, Agricultural Outlook, 27-30.

Hyytiä, N., \& Kola, J. (2006). Finnish citizens' attitudes towards multifunctional agriculture. International Food and Agribusiness Management Review, 9(3), 1-22.

Irwin, E. G., Nickerson, C. J., \& Libby, L. (2003, August). What are farmland amenities worth? Choices (Third Quarter), 21-23.

Kask, S. B., Mathews, L. G., Stewart, S., \& Rotegard, L. (2002). Blue Ridge Parkway Scenic Experience Project final report. Report for the National Park Service. Retrieved from http://www.nps.gov/blri/ parkmgmt/upload/ACF587.pdf

Kirby, L. D., Jackson, C., \& Perrett, A. (2007). Growing local: Expanding the western North Carolina food and farm economy. Retrieved from the Appalachian Sustainable Agriculture Project website: http://www.asapconnections.org/special/research /Reports/GrowingLocal.pdf

Kline, J., \& Wichelns, D. (1996). Public preferences regarding the goals of farmland preservation programs. Land Economics, 72, 538-549. http://dx.doi.org/10.2307/3146914
Knickel, K., Kröger, M., Bruckheimer, K., \& Engwall, Y. (2009). The challenge of evaluating policies for promoting the multifunctionality of agriculture: When "good" questions cannot be answered quantitatively and "quantitative answers are not that good." Journal of Environmental Policy \& Planning, 11(4), 347-367. http://dx.doi.org/10.1080/ 15239080903033945

Kuminoff, N. V. (2009). Using a bundled amenity model to estimate the value of cropland open space and determine an optimal buffer zone. Journal of Agricultural and Resource Economics, 34(1), 68-90.

Lankoski, J., \& Ollikainen, M. (2001). Policy design for multifunctional agriculture. MTT Agrifood Research Finland Working Papers 6/2001. Helsinki: MTT Agrifood Research Finland.

Lenihan, M. H., Brasier, K. J., \& Stedman, R. C. (2009). Perceptions of agriculture's multifunctional role among rural Pennsylvanians. Research in Rural Sociology and Development, 14, 127-149. http://dx.doi.org/10.1108/S10571922(2009)0000014008

Lindemann-Matthies, P., Briegel, R., Schupbach, B., \& Junge, X. (2010). Aesthetic preference for a Swiss alpine landscape: The impact of different agricultural land-use with different biodiversity. Landscape and Urban Planning, 98(2), 99-109. http://dx.doi.org/10.1016/j.landurbplan. 2010.07.015

Lynch, L., \& Duke, J. M. (2007). Economic benefits of farmland preservation: Evidence from the United States. University of Maryland College Park, Department of Agricultural and Resource Economics Working Paper 07-04. Retrieved from http://ageconsearch. umn.edu/bitstream/7342/2/wp070004.pdf

Lynch, L., \& Musser, W. N. (2001). A relative efficiency analysis of farmland preservation programs, Land Economics, 77(4), 577-594. http://dx.doi.org/10.2307/3146942

Mathews, L. G. (2009). The Farmland V alues Project summary statistics. Retrieved from http://www2.unca.edu/farmlandvalues/results.htm

Mathews, L. G., Stewart, S., \& Kask, S. B. (2003). Blue Ridge Parkway Scenic Experience Project phase 2 final report. Retrieved from http://www.nps.gov/blri/parkmgmt/scenicexperience-project.htm 
Mathews, L. G., \& Rex, A. (2011). Incorporating scenic quality and cultural heritage into farmland valuation: Results from an enhanced LESA model. Journal of Conservation Planning, 7, 39-59.

McClead, D.,Woirhye, J., Kruse, C., \& Menkhaus, D. (1998). Private open space and public concerns. Review of Agricultural Economics, 20, 644-653.

McConnell, K. E. (1989). The optimal quantity of land in agriculture. Northeastern Journal of Agricultural and Resource Economics, 18(2), 63-72.

Moon, W., \& Chang, J. (2010). Bivariate probit analysis of public attitudes toward multifunctionality of agriculture in the U.S. Paper presented at the Agricultural and Applied Economics Association Annual Meeting, Denver, Colorado, July 26-29, 2010.

Moon, W., \& Griffith, W. (2010). Assessing public preferences and holistic economic value for multifunctional agriculture in the U.S. Paper presented at the Southern Agricultural Economics Association annual meeting, Orlando, Florida, February 6-9, 2010.

Nickerson, C. J., \& Hellerstein, D. (2003). Protecting rural amenities through farmland preservation programs. Agricultural and Resource Economics Review, 32(1), 129-144.

Organization for Economic Cooperation and Development (OECD). (2001). Multifunctionality: Towards an analytical framework. Paris: Organization for Economic Cooperation and Development.

Parra-López, C., Groot, J. C. J., Carmona-Torres, C., \& Rossing, W. A. H. (2008). Integrating public demands into model-based design for multifunctional agriculture: An application to intensive Dutch dairy landscapes. Ecological Economics, 67(4), 538-551.

http://dx.doi.org/10.1016/j.ecolecon.2008.01.007

Pease, J. R., \& Coughlin, R. E. (1996). Land evaluation and site assessment: A guidebook for rating agricultural lands (second edition). Ankeny, Iowa: Soil and Water Conservation Society.

Perry, H., Robison, N., Chavez, D., Taja, O., Hillari, C., Shanklin, D., \& Wyon, J. (1999). Attaining health for all through community partnerships: Principles of census-based, impact-oriented (CBIO) approach to primary health care developed in Bolivia, South America. Social Science and Medicine, 48(8), 10531067. http://dx.doi.org/10.1016/S02779536(98)00406-7
Randall, A. (2002). Valuing the outputs of multifunctional agriculture. European Review of Agricultural Economics, 29(3), 289-307. http://dx.doi.org/10.1093/eurrag/29.3.289

Rex, A., Mathews, L. G., \& Lancaster, A. (in press). TVAL-Farm: A qualitative enhancement of the LESA model. International Journal of Geospatial Research.

Riddle, S. (2011, March). The downtown survey report. Report presented to Asheville Downtown Association.

Sakuyama, T. (2005). A decade of debate over non-trade concerns and agricultural trade liberalization: Convergences, remaining conflicts and a way forward. International Journal of Agricultural Resources, Governance and Ecology, 4(3/4), 203-215. http://dx.doi.org/10.1504/IJARGE.2005.007451

Sayadi, S., González-Roa, M. C., \& Calatrava-Requena, J. (2009). Public preferences for landscape features: The case of agricultural landscape in mountainous Mediterranean areas. Land Use Policy, 26(2), 334 344. http://dx.doi.org/10.1016/j.landusepol. 2008.04.003

Shrestha, B. (2010, May 19). Plans in hand, but money isn't for Haywood Park. Smoky Mountain News. http://www.smokymountainnews.com/index.php/ calendar/item/797-plans-in-hand-but-moneyisn $\% \mathrm{E} 2 \% 80 \% 99 \mathrm{t}$-for-haywood-park

Starnes, R. D. (2005). Creating the land of the sky: Tourism and society in western North Carolina. Tuscaloosa, Alabama: University of Alabama Press.

Swinbank, A. (2001, November 29). Multifunctionality: A European euphemism for protection? Farming and Wildlife Advisory Group Conference. National Agricultural Centre, Stoneleigh, U.K. Available from http:// citeseerx.ist.psu.edu/viewdoc/ summary?doi=10.1.1.194.7859

United States Census Bureau. (2010). State \& county quickfacts. Retrieved January 31, 2010, from http://quickfacts.census.gov/qfd/states

United States Census Bureau. (2011). 2010 census data. Retrieved May 5, 2011, from http://2010.census.gov/2010census/data

United States Department of Agriculture (USDA). (2008). FY 2008 budget summary and annual performance plan. Retrieved May 5, 2011, from http://www.obpa.usda.gov/budsum/ FY08budsum.pdf 
Journal of Agriculture, Food Systems, and Community Development ISSN: 2152-0801 online

www.AgDevJournal.com

United States Department of Agriculture, National Agricultural Statistics Service (USDA NASS). (2008). 2007 Census of Agriculture county summary highlights. Retrieved March 15, 2011, from http://www.agcensus.usda.gov/Publications/2007 LFull Report/Volume 1, Chapter 2 County Lev el/North_Carolina/st37_2_001_001.pdf
Vera-Toscano, E., Gómez-Limón, J. A., Moyano Estrada, E., \& Garrido Fernández, F. (2007). Individuals' opinion on agricultural multifunctionality performance. Spanish Journal of Agricultural Research, 5(3), 271-284. 
Journal of Agriculture, Food Systems, and Community Development ISSN: 2152-0801 online www.AgDevJournal.com 